Diversidad y patrones de actividad de los medianos y grandes

mamíferos del Parque Nacional Natural Tamá y su zona de amortiguación, Colombia

\title{
Terrestrial medium and large-sized mammal's diversity and activity patterns from Tamá National Natural Park and buffer zone, Colombia
}

\author{
Carlos H. Cáceres-Martínez ${ }^{1 *}$, Aldemar A. Acevedo Rincón ${ }^{1}$ y José F. González-Maya2, 3
}

\begin{abstract}
1 Universidad de Pamplona, Grupo de Investigación en Ecología y Biogeografía, Km 1, Vía a Bucaramanga, Barrio El Buque, Edificio Camilo Daza, 543050. Pamplona, Colombia. Email: charli1391@gmail.com (CHC-M), bioaldemar@gmail.com (AAAR).

2 Proyecto de Conservación de Aguas y Tierras, ProCAT Colombia/Internacional. Carrera 13 \# 96-82, Of. 202. Bogotá, Colombia. ${ }^{3}$ Instituto de Ecología, Universidad Nacional Autónoma de México, Circuito Exterior s/n, Ciudad Universitaria, Ciudad de México, México. Email: jfgonzalezmaya@gmail.com (JFG-M).

* Corresponding author
\end{abstract}

The eastern mountain range of Andes in Colombia is one of the least studied areas for mammals in the country, yet, potentially one of the most diverse. Here we present the first survey of medium and large-sized mammals for Tamá National Natural Park (NNP) and La Carpa and La Rochela buffer areas, as basic information for the conservation and management of the NNP, including the potential inclusion of these buffer zones as part of the NNP. We used different complementary survey techniques (i. e., camera-traps, transects and interviews) to assess the diversity of these mammals in a $216 \mathrm{~km}^{2}$ area of the park; our effort included 72 linear transects of $1.8 \mathrm{Km}$, opportunistic sampling sessions, 16,714 camera trap-days, 39 structured interviews and indirect records and direct observation of animals. We recorded 21 species of mammals classified in 8 orders and 16 families distributed in four conservation categories. Complementary methods significantly improved the results. We found a dominant nocturnal activity pattern for the assemblage and low activity overlapping among most species. This is the first assessment of medium and large-sized mammal's diversity for Tamá NNP and for most North-eastern Andes in the country. Our results highlight the presence of large threatened species such as Tremarctos ornatus, Puma concolor and Mazama rufina. Our results could serve as basis for the conservation planning and management of the protected area and its buffer zones, and the potential expansion of the park.

La cordillera Oriental de los Andes en Colombia es una de las áreas menos estudiadas para los mamíferos en Colombia, sin embargo, potencialmente, una de las más diversas en el país. Aquí presentamos la primera evaluación de los mamíferos medianos y grandes para el Parque Nacional Natural (PNN) Tamá y las zonas de amortiguamiento La Carpa y La Rochela, como información básica para la conservación y manejo del PNN y el manejo del área, incluyendo la potencial inclusión de estas zonas como parte del PNN. Utilizamos diferentes técnicas de muestreo complementarias (i. e., Cámaras trampa, transectos y entrevistas) para evaluar la diversidad de los mamíferos en $216 \mathrm{~km}^{2}$; nuestro esfuerzo incluyó 72 transectos lineales de $1.8 \mathrm{~km}$, sesiones de muestreo oportunistas, 16,714 días/trampa, 39 entrevistas estructuradas y registros indirectos y la observación directa de los animales. Se registraron 21 especies de mamíferos clasificadas en 8 órdenes y 16 familias distribuidas en cuatro categorías de conservación. Esta es la primera evaluación de la diversidad de mamíferos medianos y grandes del PNN Tamá y para la mayor parte de los Andes Nororientales del país. Nuestros resultados resaltan la presencia de especies amenazadas grandes como Tremarctos ornatus, Puma concolor and Mazama rufina. Nuestros resultados servirán de base para el manejo y planificación de conservación del área protegida y sus zonas de amortiguamiento, así como la potencial ampliación del mismo.

Key words: Andes; biodiversity; conservation; mammals; protected areas.

(c) 2016 Asociación Mexicana de Mastozoología, www.mastozoologiamexicana.org 


\section{Introduction}

Colombia is considered a mega-diverse country due to its great variability of ecosystems and geography, which has resulted in a wide range of life forms product of diversification caused by the evolutionary processes occurring in the national territory (Kattan and Franco 2004; RodríguezMahecha et al. 2006). This richness is reflected in most groups, where specifically for mammals, Colombia has recorded to date at least 518 species (Solari et al. 2013; Ramírez-Chaves et al. 2016), but with a very high potential of a considerable higher number.

Previous analyses of mammal diversity in the country have identified the Andean region as the one with the highest number of species, followed by the Amazon and the Pacific regions (Solari et al. 2013). The most plausible reason of this high diversity is the branching of this mountain range in the country, generating a large number of micro-climates and conditions that have led to a significant number of biomes and ecosystems, which in exchange impacted many species' diversification processes (Prado and Bonilla 2009). However, despite this remarkable diversity, the region has received limited research attention, with considerable gaps on many ecological aspects of the group, including the conservation status of many species, especially for medium- and large-sized species (Sánchez et al. 2004; Ramírez and Pérez 2006; Ramírez-Chaves and Noguera-Urbano 2010; Ramírez-Chaves et al. 2013). To date, most research has centered mainly on small mammals, bats, and/or single species studies (Sánchez et al. 2004; Prado and Bonilla 2009; Rodríguez-Posada 2010), still with many ecological and conservation questions pending regarding the other groups.

For Colombia, most of the research in the Andes has focused mainly in a few regions (i. e., Cauca, Nariño, Cundinamarca, Caldas and Antioquia departments; Castaño et al. 2003; Sánchez et al. 2004; Ramírez-Chaves and Noguera-Urbano 2010; Solari et al. 2013), with a significant portion of the range still mostly unknown for most groups (i. e., Santander, Norte de Santander and Boyacá). Unfortunately, these unknown regions are also suffering accelerated landscape transformation, and historically, the growth and expansion of human settlements has also cause an increase in the number of threatened species (Armenteras et al. 2003; Forero-Medina and Joppa 2010). Moreover, among the least known regions, the Northeast of the Andean mountain range has received the lowest research attention historically (Caceres-Martinez and Acevedo 2014). For this specific region, information regarding species richness, ecology and conservation status, especially for medium and large-sized mammals, is almost inexistent, even within protected areas (Castaño et al. 2003; Ramírez-Chaves et al. 2016; Ramírez-Chaves and Noguera-Urbano 2010; Caceres-Martinez and Acevedo 2014), mostly caused by social and violence problems historically operating in the region.

Norte de Santander Department, located in the Northeast region of the Andes mountain, includes three protected areas, considered among the most valuable within the National Protected Areas System: Catatumbo-Bari National Natural Park (NNP), Estoraques NNP, and Tamá NNP. For these areas, no information existed regarding mammal diversity until our recent research efforts conducted in Tamá NNP (Caceres-Martinez and Acevedo 2014; Cáceres-Martínez et al. $\underline{2015}$ ), although some information available on gray literature for the same area is available (i.e., thesis and technical reports). In order to support conservation strategies for mammals locally and regionally, generating basic information for the region has become a critical need, especially for these protected areas (Ceballos and Brown 1995; O'Brien 2008; Tobler et al. 2008). We report in this study the first assessment of medium- and large-sized mammals' diversity for Tamá NNP and its buffer zones as support for adequate protected area management and as basis for the potential expansion of the park. 


\section{Materials and methods}

Study area. The study was conducted in Tamá NNP and buffer zones (La Carpa and La Rochela areas; $7^{\circ} 14^{\prime} 36^{\prime \prime} \mathrm{N},-72^{\circ} 13^{\prime} 19^{\prime \prime} \mathrm{W}, \mathrm{WGS} 84$ ), in the Department of Norte de Santander, in the northern most extreme of the Colombian Andes mountain range on the border with Venezuela. With an elevation gradient ranging from 350 to 3,500 m (Setina et al. 2012), Tamá NNP and its buffer zone has an approximate area of 53,000 ha (48,000 ha of official park) and is composed mostly of Andean and Sub-Andean forests (36.6 and $27.9 \%$, respectively), Tropical forests (18.8 \%), and a lower proportion of cloud forests (7.8\%) and Páramo (8.9\%; Holdridge 1987; Minambiente 2008). These protected areas comprise the entire Tamá massif, commonly known as the Tamá Binational Park (Minambiente 2008). The most significant threats to the area include deforestation on the buffer areas and a significant pressure from hunting (Caceres-Martinez and Acevedo 2014; Cáceres-Martínez et al. 2015). More recently, La Carpa and La Rochela, two areas located in the buffer zone, were assigned for management under the NNP administration, but are not currently officially included in the park boundaries; we also included sites in these areas in order to provide baseline data for its potential inclusion in the protected area.

\section{Methods}

Our sampling design included 24 quadrants of $9 \mathrm{~km}^{2}$ that were surveyed between June 2012 and May 2015 (Figure 1) covering an area of approximately $216 \mathrm{~km}^{2}$ and an elevation range between 1,843 and 3,445 m. We used four complementary methods: camera traps, transects, opportunistic observations and interviews.

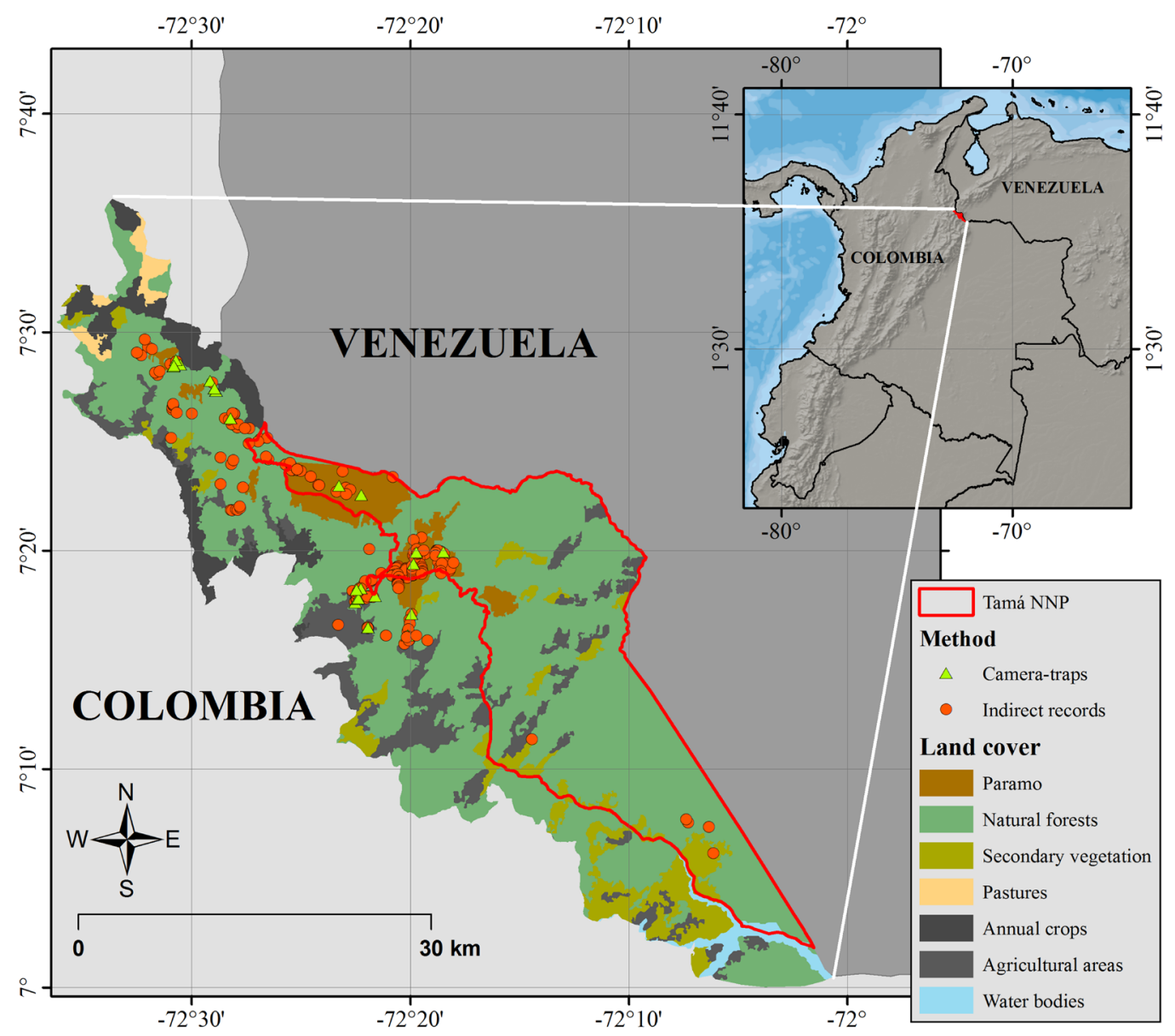

Figure 1. Geographic location of Tamá National Natural Park and its buffer zone and location of Camera-traps and Indirect records where medium and large-sized terrestrial mammals'records were obtained. 
Surveys with camera-traps (Reconyx RM45, Reconyx HC500, Bushnell Trophy Cam, and Primos Truth Cam 35) included 58 single-camera stations and three paired-camera stations for a total sampling effort of 16,714 camera-trap days. Camera trap stations were separated approximately $1 \mathrm{~km}$ depending on the terrain, without any preset spatial pattern. Stations were selected by identifying random sites within the grid with signs of the presence of medium- and large-sized mammals (Goldstein et al. 2013). Capture rates were estimated as the number of detections of a species relative to the total number of detections, scaled to 100 trap-nights (Mosquera-Muñoz et al. 2014). Activity patterns were described for species with enough independent detections (González-Maya et al. 2009); Kuiper tests (K) were used to assess the homogeneity across 24-hour day periods for the entire assemblage and for each species (González-Maya et al. 2015). All species were classified according to the predominant activity period in Diurnal (06h00 to 18h00), Nocturnal (18h00 to 06h00) and Cathemeral (activity on both periods; González-Maya et al. 2009). Contingency tables and Morisita-Horn index were used to test overlapping among activity periods for all species.

Transect sampling included three $1.8 \mathrm{~km}$ transects on each quadrant (a total of 72 transects), surveyed between 8:00 and 18:00 $\mathrm{h}$ during the total sampling period, comprising an effort of 190 days (i. e., 1,900 man-hours), and accounting for direct observation and tracks and signs such as feces, hair, tracks, corpses and/or skeletal remains, foraging activity, trails, marking sites and dens/burrows (Guzmán-Lenis and Camargo-Sanabria 2004). For each detection we recorded a description of the site, type of evidence, location, photographic record and elevation. Hair, feces, and skeletal remains were stored in labeled plastic bags before processing and identification in the laboratory of Ecology and Biogeography (GIEB), University of Pamplona. Samples processing included washing with distilled water on strainers of $0.5 \mu \mathrm{m}$, drying at room temperature, and visual examination of sample components. Samples were compared with reference material from the mammal collection of the Institute of Natural Sciences of the National University and the Museum of Sciences "José Celestino Mutis" of the University of Pamplona and deposited in the general mammal collection at the latter museum. Opportunistic observations were obtained during fieldwork, and include those that were not specifically located on a specific transect.

Interview surveys were conducted with communities in 13 localities of the area, obtaining a total of 39 interviews of independent family settlements. Interviews were constructed following a semi-structured open-ended questions structure, trying to account for an interpretive and participatory approach (White et al. 2005). Interviews were supported with camera trap and fieldguide photos and illustrations (Emmons and Feer 1997; Ceballos and Oliva 2005; Aranda 2012). For all interviews we asked the interviewed person for evidence in order to obtain supporting material for all records (Figure 3, Table 1). We based our field identification on field guides (Emmons and Feer 1997; Ceballos and Oliva 2005; Aranda 2012) and followed Wilson and Reeder (2005) for general taxonomic classification.

We estimated species' accumulation curves for each method (i. e., Camera-traps and Indirect records) and their combination, adjusting to three predefined models (Clench, Lineal Dependence and Logarithmic), and estimated rarefaction curves also for the three datasets using software EstimateS v. 9 (Espinosa 2003; Colwell 2013) and R environment (R Core Team 2013).

\section{Results}

We recorded 21 species of medium- and large-sized mammals distributed in 8 orders, 16 families and 21 genera (Table 1). Our species accumulation curve indicated a significant completeness of the indirect record surveys (0.89) but not as high for the camera-traps method (0.59). The combination of methods resulted on a good accumulation (0.85; Figure 2). Comparison of methods according to richness indicated the combination of survey methods accounted for a larger richness, followed by camera-traps and Indirect records (Figure 2). 
Table 1. Medium and large-sized terrestrial mammals recorded at Tamá National Natural Park, Colombia. Methods: CT: Camera-trap, IR: Indirect Record, DO: Direct Observation and I: Interview. Conservation status: NT: Near Threatened, LC: Least Concern, VU: Vulnerable. MCNUP-M: Museo de Historia Natural Universidad de Pamplona-Mamíferos.

\begin{tabular}{|c|c|c|c|c|c|}
\hline \multirow{2}{*}{ Taxa } & \multirow{2}{*}{ Methods } & \multirow{2}{*}{ Voucher } & \multicolumn{3}{|c|}{ Conservation category } \\
\hline & & & National & IUCN 2015 & CITES 2015 \\
\hline \multicolumn{6}{|l|}{ DIDELPHIMORPHIA } \\
\hline \multicolumn{6}{|l|}{ Didelphidae } \\
\hline Didelphis pernigra (Allen, 1900) & $\mathrm{CT}, \mathrm{I}$ & & - & LC & - \\
\hline \multicolumn{6}{|l|}{ CINGULATA } \\
\hline \multicolumn{6}{|l|}{ Dasypodidae } \\
\hline Dasypus novemcinctus (Linnaeus, 1758) & IR, I & MCNUP-M-85 & - & LC & - \\
\hline \multicolumn{6}{|l|}{ PILOSA } \\
\hline \multicolumn{6}{|l|}{ Megalonychidae } \\
\hline Choloepus hoffmanni (Peters, 1858) & IR, I & MCNUP-M-86 & - & LC & - \\
\hline \multicolumn{6}{|l|}{ Myrmecophagidae } \\
\hline Tamándua mexicana (Saussure, 1860) & I & & - & LC & - \\
\hline \multicolumn{6}{|l|}{ PRIMATES } \\
\hline \multicolumn{6}{|l|}{$\underline{\text { Atelidae }}$} \\
\hline Alouatta seniculus (Linnaeus, 1766) & DO, I & & - & LC & - \\
\hline \multicolumn{6}{|l|}{ RODENTIA } \\
\hline \multicolumn{6}{|l|}{ Cuniculidae } \\
\hline Cuniculus paca (Linnaeus, 1766) & DO, IR, I & & - & LC & - \\
\hline $\begin{array}{l}\text { Cuniculus tackzanowskii (Stolzmann, } \\
\text { 1865) }\end{array}$ & CT, IR, I & MCNUP-M-70 & - & NT & - \\
\hline \multicolumn{6}{|l|}{ Dasyproctidae } \\
\hline Dasyprocta punctata (Gray, 1842) & CT, IR, I & MCNUP-M-75 & - & LC & - \\
\hline \multicolumn{6}{|l|}{ Sciuridae } \\
\hline Sciurus granatensis (Humboldt, 1811) & $\mathrm{CT}, \mathrm{DO}, \mathrm{I}$ & & - & LC & - \\
\hline \multicolumn{6}{|l|}{ CARNIVORA } \\
\hline \multicolumn{6}{|l|}{ Canidae } \\
\hline Cerdocyon thous (Linnaeus, 1766) & IR, I & MCNUP-M-77 & - & LC & II \\
\hline \multicolumn{6}{|l|}{ Felidae } \\
\hline Leopardus wiedii (Schinz, 1821) & CT, DO, IR, I & MCNUP-M-84 & NT & NT & I \\
\hline Puma concolor (Linnaeus, 1771) & $\mathrm{CT}, \mathrm{DO}, \mathrm{IR}, \mathrm{I}$ & MCNUP-M-83 & NT & LC & I \\
\hline Panthera onca (Linnaeus, 1758) & $\mathrm{IR}, \mathrm{I}$ & & NT & NT & I \\
\hline \multicolumn{6}{|l|}{ Mephitidae } \\
\hline $\begin{array}{l}\text { Conepatus semistriatus (Boddaert, } \\
1785 \text { ) }\end{array}$ & CT, IR, I & & - & LC & - \\
\hline \multicolumn{6}{|l|}{ Mustelidae } \\
\hline Mustela frenata (Lichtenstein, 1831) & CT, DO, I & & - & LC & - \\
\hline \multicolumn{6}{|l|}{ Procyonidae } \\
\hline Nasua nasua (Linnaeus, 1766) & CT, DO, IR, I & MCNUP-M-76 & - & LC & - \\
\hline Nasuella olivacea (Gray, 1865) & CT, IR, I & $\begin{array}{l}\text { MCNUP-M-38, 41, 48, } \\
52,80\end{array}$ & - & DD & - \\
\hline Potos flavus (Schreber, 1774) & OD, IR. & MCNUP-M-78 & - & $\mathrm{LC}$ & - \\
\hline \multicolumn{6}{|l|}{ Ursidae } \\
\hline Tremarctos ornatus (Cuvier, 1825) & CT, IR, I & MCNUP-M-1-20 & $\mathrm{VU}$ & VU & I \\
\hline CETARTIODACTYLA & & & & & \\
\hline Cervidae & & & & & \\
\hline Mazama rufina (Pucheran, 1851) & CT, IR, I & MCNUP-M-79, 83 & - & VU & - \\
\hline
\end{tabular}



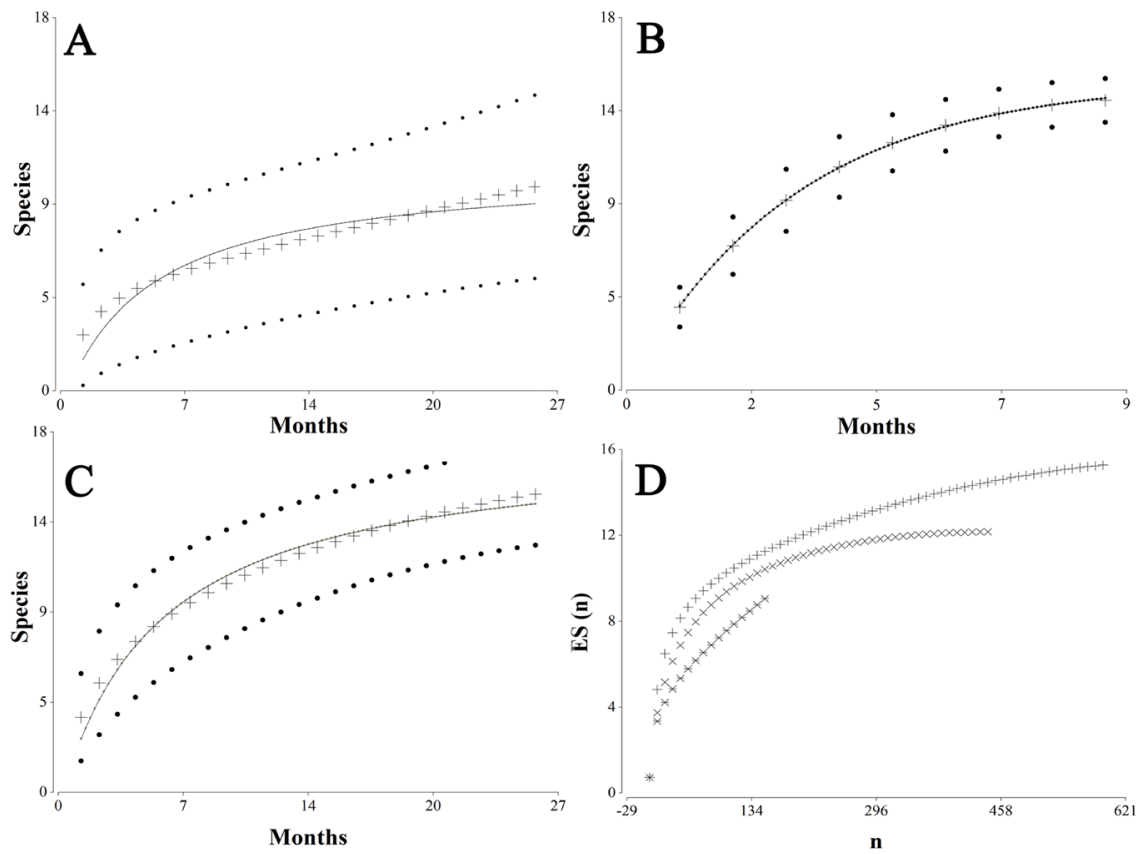

Figure 2. Species accumulation curve for (A) Camera-traps-CT, (B) Indirect records-IR and (C) combined methods and $(D)$ rarefaction curves for the two methods $(X=C T ;+=I R)$ and combined $(*)$ for medium and large-sized terrestrial mammals detected at Tamá National Natural Park, Colombia.
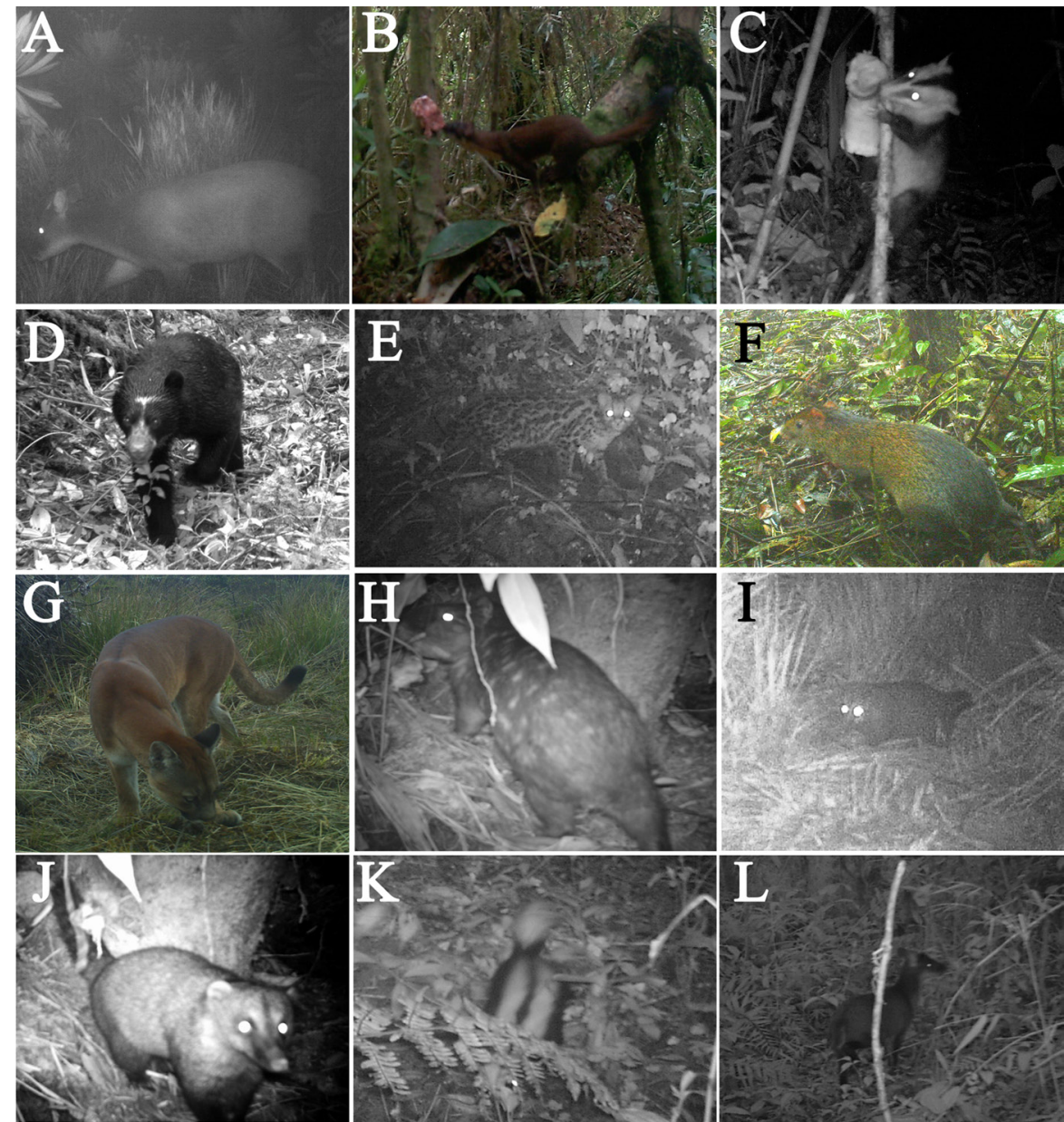

Figure 3. Species of medium and large-sized terrestrial mammals detected by camera traps at Tamá National Natural Park, Colombia: A) Mazama rufina, B) Mustela frenata, C) Didelphis pernigra, D) Tremarctos ornatus, E) Leopardus wiedii, F) Dasyprocta punctata, G) Puma concolor, H) Cuniculus taczanowskii, I) Nasua nasua, J) Nasuella olivacea, K) Conepatus semistriatus and L) Mazama rufina. 
We obtained a total of 40,068 photographs comprising 12 species of mediumand large-sized mammals (Figure 3, Table 2), of which $6 \%(2,423)$ of the photographs were wild mammals and $7.2 \%$ corresponded to introduced species such as domestic cattle and domestic dogs (Table 2), while $87 \%$ of the pictures corresponded to false positives, mostly due to vegetation movement and direct light. The most frequently detected (i.e., capture rate $C R$ ) species were Nasua nasua ( $C R=18$ ind/100 trap-nights), Didelphis pernigra $(C R=16.4)$, and Cuniculus taczanowskii $(C R=13.3)$, while species such as Leopardus wiedii ( $C R=1.6)$, Sciurus granatensis ( $C R=2.3)$, and Conepatus semistriatus ( $C R=1.6)$, were the least frequent (Table 2$)$. Activity patterns showed a dominant nocturnal activity for the entire assemblage ( $\mathrm{K}=70.74, P<0.001)$, as also found for most of the species excepting D. punctata, S. granatensis and M. frenata, while species such as P. concolor and N. nasua showed cathemeral activity (Figure 4). Activity patterns mean $( \pm S D)$ overlapping among all species was low $(0.13 \pm 0.16)$. The species pairs with the highest overlap values were C. taczanowskii and N. nasua (0.67), M. frenata and T. ornatus (0.55) and D. punctata and S. granatensis (0.52; Figure 5A).

Table 2. Activity period, Kuiper test estimator ( ${ }^{*}$ indicates significant differences from homogeneity $P<0.001$ ), number of records and capture rate from camera traps for medium and large-sized terrestrial mammals recorded at Tamá National Natural Park, Colombia.

\begin{tabular}{|c|c|c|c|c|}
\hline Specie & Activity hours & Kuiper test & $\begin{array}{l}\text { Records } \\
\text { (100 trap- } \\
\text { days) }\end{array}$ & Capture rate \\
\hline Didelphis pernigra & Nocturnal & $\mathrm{K}=123.28^{*}$ & 21 & 16.4 \\
\hline Cuniculus tackzanowskii & Nocturnal & $\mathrm{K}=158.29^{*}$ & 17 & 13.28 \\
\hline Dasyprocta punctata & Diurnal & $\mathrm{K}=174.27^{*}$ & 6 & 4.68 \\
\hline Sciurus granatensis & Diurnal & $\mathrm{K}=187.25^{*}$ & 3 & 2.34 \\
\hline Leopardus wiedii & Nocturnal & $\mathrm{K}=187.25^{*}$ & 2 & 1.56 \\
\hline Puma concolor & Cathemeral & $K=183.75^{*}$ & 4 & 3.12 \\
\hline Conepatus semistriatus & Nocturnal & $\mathrm{K}=187.25^{*}$ & 2 & 1.56 \\
\hline Mustela frenata & Diurnal & $\mathrm{K}=178.38^{*}$ & 3 & 2.34 \\
\hline Nasua nasua & Cathemeral & $K=144.75^{*}$ & 22 & 17.18 \\
\hline Nasuella olivacea & Nocturnal & $\mathrm{K}=187.88^{*}$ & 4 & 3.12 \\
\hline Tremarctos ornatus & Diurnal & $K=163.29^{*}$ & 12 & 9.37 \\
\hline Mazama rufina & Nocturnal & $\mathrm{K}=168.39^{*}$ & 11 & 8.59 \\
\hline \multicolumn{5}{|c|}{ Domestic animals } \\
\hline Cattle & Diurnal & & 14 & 10.93 \\
\hline Dogs & Diurnal & & 3 & 2.34 \\
\hline Horses & Diurnal & & 4 & 3.12 \\
\hline Total & & & 128 & \\
\hline
\end{tabular}

We also obtained 3,278 indirect records, both from transects and opportunistic observations, of which the most abundant were feeding signs $(2,471 ; 75.4 \%)$ followed by feces $(287 ; 8.7 \%)$, while the least common were nests/dens $(21 ; 0.6 \%)$, and climbing marks (46; $1.4 \%$; Figure 5B). Four species were identified from skeletal remains and/ or partially consumed carcasses preyed by Tremarctos ornatus, Puma concolor, and Leopardus wiedii: which included N. olivacea, Potus flavus, and Mazama rufina. Also, in 287 feces of these species, we detected remains of Cuniculus taczanowskii, $N$. olivacea, N. nasua, M. rufina, Dasyprocta punctata, C. paca, Dasypus novemcinctus, and Choloepus hoffmanni. 
Nine species were directly observed and that were possible to identify on the field: P. concolor, Alouatta seniculus, Mustela frenata, Leopardus wiedii, Sciurus granatensis, N. nasua, P. flavus and C. paca. From corroborated information derived from interviews, we obtained material (i. e., photographs and animals parts from hunters) and evidence of presence and harvest of 20 species (Table 1, Figure 6). Some small mammals were also occasionally observed or detected (e.g., Cryptotis tamensis), but are not included in this report.
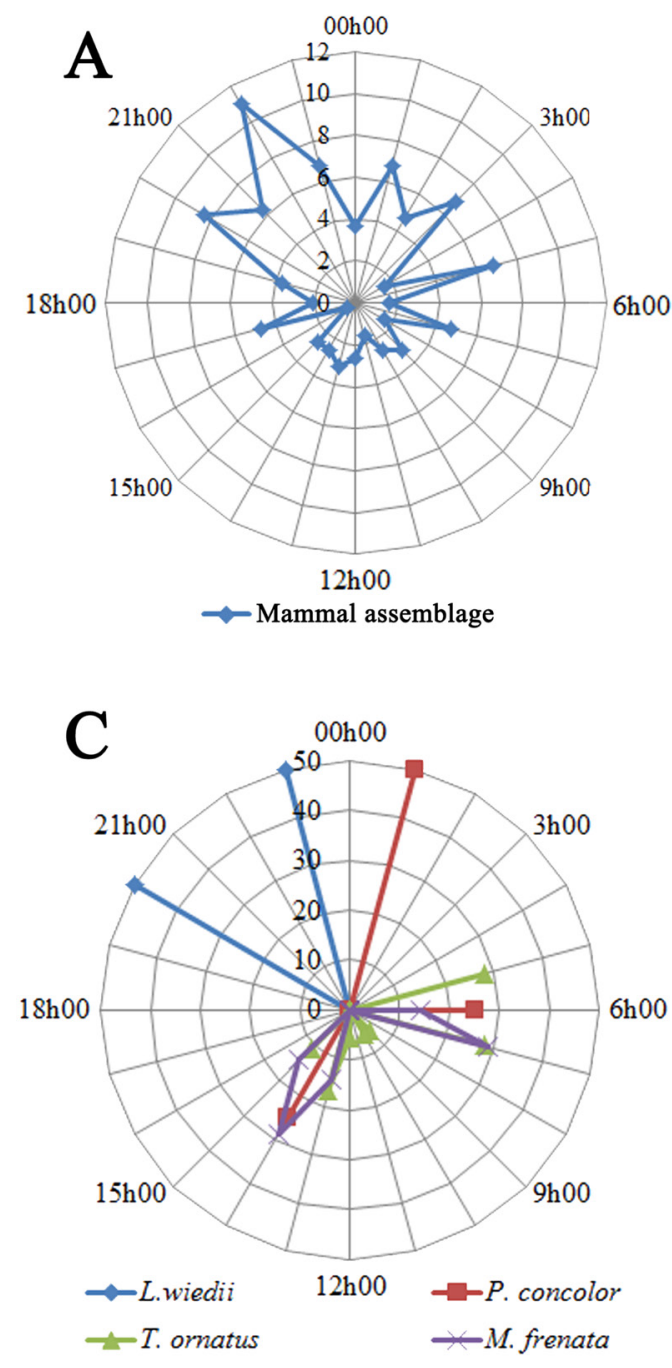
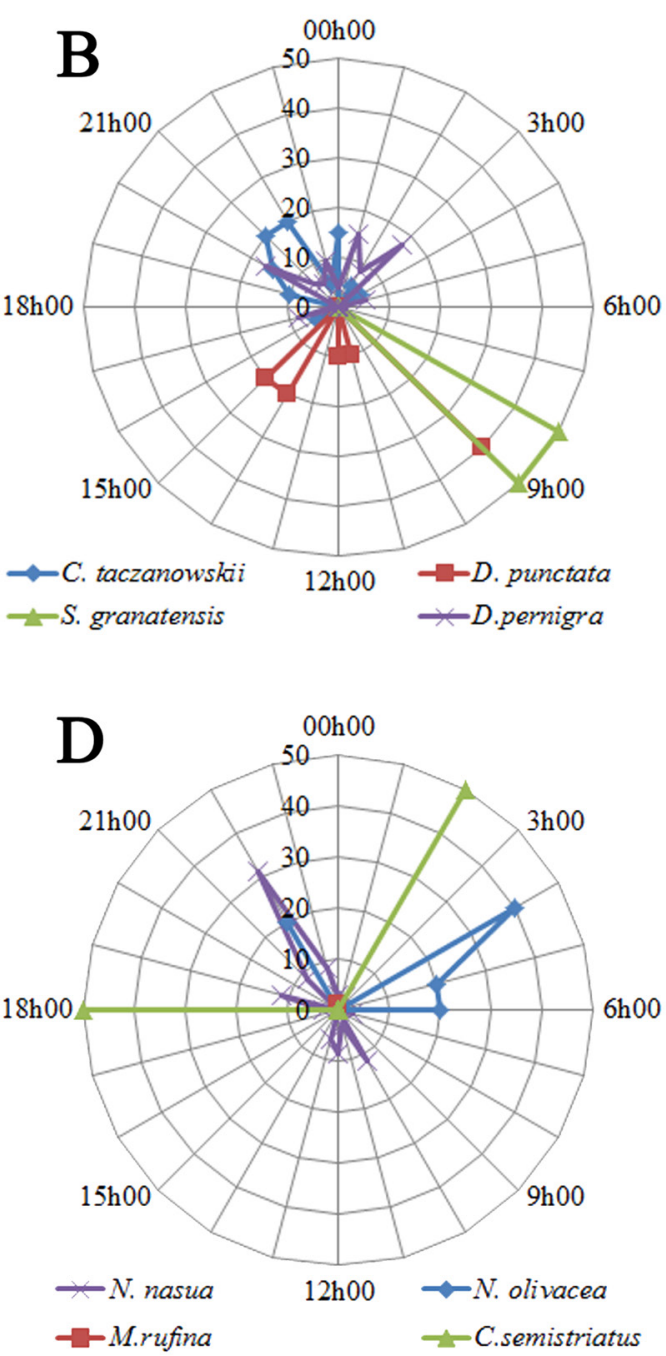

Figure 4. Activity patters of (A) all mammals, (B) Rodents and marsupials, (C) Felidae, Ursidae and Mustelidae and (D) Procyonidae, Cervidae and Mephitidae.

\section{Discussion}

This study constitutes the first estimate of the medium- and large-sized mammals' species richness from Tamá NNP and surrounding buffer areas. Although the number of species recorded could be considered low, given the extensive sampling effort we consider it a good first approach to mammal diversity in the area (Lira-Torres and Briones-Salas 2012). The confirmed presence of large species in the park, currently considered threatened for most the country (Rodríguez-Mahecha et al. 2006), highlight the importance of Tamá NNP and the La Carpa y La Rochela buffer zones for wild mammal conservation in the country. Interviews and anecdotal records indicate 
that historically the area has, and continue to, experience intensive hunting, which may have caused a dramatic decline in many mammal populations and may suggest that some species, such as $T$. ornatus, are much more threatened than currently thought in Northeastern Colombia (García-Rangel 2012; Caceres-Martinez and Acevedo 2014). Furthermore, many areas of the park were not surveyed given the armed conflict that still affects the area, especially in the lowlands. Other potentially present species, such as Tayassu pecari, Puma yagouaroundi, and Lontra longicaudis, were not recorded but are likely present in the park, which was also suggested by park rangers and local hunters. Our approach of using different survey methods is likely appropriate given that only with the two survey methods we obtained a reliable inventory of medium and large-sized mammals for the park (Sánchez et al. 2004; Norris et al. 2012). Nevertheless, a more geographically extensive survey design would likely register other species, and would provide more insights into distribution and habitat use in the area.
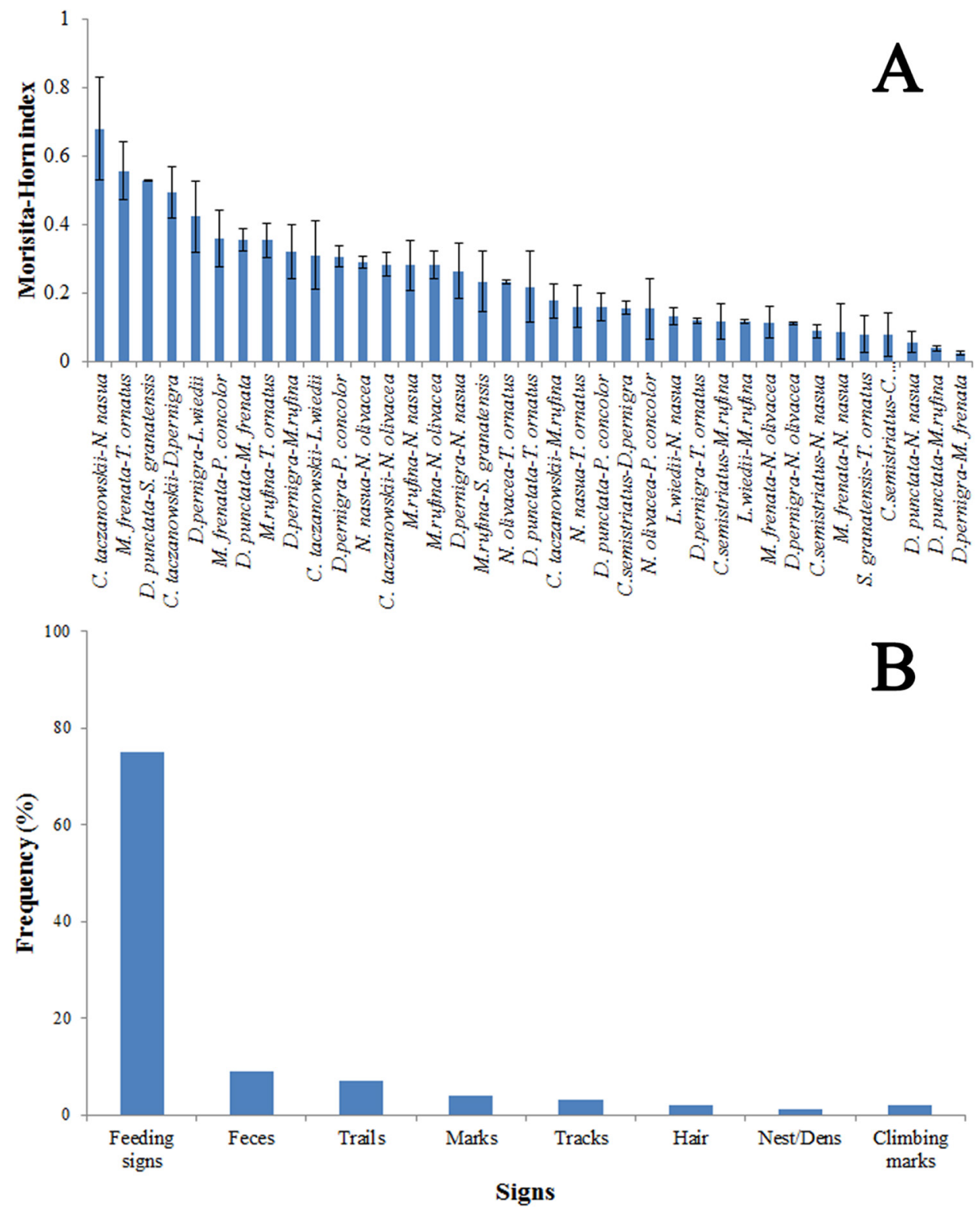

Figure 5. A) Morisita-Horn (SE) overlapping index among pair-wise species activity patterns comparisons and (B) frequency of indirect signs of medium and large-sized terrestrial mammals recorded at Tamá National Natural Park, Colombia. 
M. rufina was considered absent from the eastern mountain range and still its northern distribution is not well known (Lizcano and Alvarez 2008), while M. bricenii is presumed to occur in northern Colombia in areas such as Tamá NNP (Lizcano et al. 2010). The classification and identification of $M$. bricenii and $M$. rufina have been subject to recent debate (e. g., Solari et al. 2013; Gutiérrez et al. 2015), however, according to available descriptions for both species (Barrio 2010; Gutiérrez et al. 2015), and taxon validity (Gutiérrez et al. 2015), our records correspond to M. rufina. We therefore obtained multiple records of $M$. rufina between 350 and 3,450 m, in areas of tropical forest and Páramo (i. e., Páramo del Tamá and Páramo de Santa Isabel) near the border with Venezuela, indicating that the species is mostly nocturnal and solitary, adding some lights on the scarce knowledge of this species ecology (Lizcano and Alvarez 2008; Merino and Rossi 2010).

Several species were mainly diurnal, as previously reported for T. ornatus, M. frenata, D. punctata, and S. granatensis (Smythe 1978; Castellanos et al. 2005; Jiménez et al. 2010; Zapata-Ríos and Branch 2016) as were domestic and feral species such as dogs, cattle and horses (See Table 2); however, most species (M. rufina, D. pernigra, $N$. olivacea, C. semistriatus, L. wiedii, and C. taczanowskii) were found to be more active at night consistent with previous reports (Lizcano and Alvarez 2008; González-Maya et al.2009; Jiménez et al. 2010; Zapata-Ríos and Branch 2016), and only few species were cathemeral (i. e., N. nasua and $P$. concolor). Preliminary data from our study indicate activity patterns of predators like $P$. concolor are partially concordant with the activity peaks of potential prey species (e.g., D. pernigra), which also was supported by overlapping of these species on the same localities, as previously reported for similar areas (Mosquera-Muñoz et al. 2014). Only weak overlapping was found however for main predators, likely reducing the likelihood of competition for prey-species (Jaksié et al. 1981). It is noteworthy that weak overlapping occurred among most species, although habitat use for almost the entire assemblage tended to be nocturnal. It is also important to highlight that this weak overlapping can be the result of scarce records for many species, thus having an effect derived from the small sample size (Blake et al. 2012). Although few studies exist for activity patterns in similar ecosystems, thus not allowing comparisons (Rust 1962; Richter and Schauber 2006), previous works on the subject have shown significant variation in activity patterns of most species due to presence of domestic animals (Zapata-Ríos and Branch 2016). Previous studies report that the presence of these animals, especially feral dogs, can turn most of the assemblage towards more nocturnal predominance (Zapata-Ríos and Branch 2016), which may be one of the causes for dominant nocturnal activities reflected in our data. However, more precise occupancy estimates could shed more lights on these patterns in the area, especially for species such as M. rufina and T. ornatus (PérezIrineo and Santos-Moreno 2013).

Lack of knowledge of the medium- and large-sized mammals at local and regional levels is a serious shortcoming that can lead to the disappearance and/or local extinction of many species, especially large predators such as T. ornatus, P. concolor, and Panthera onca due to their small populations, large space requirements and the many threats they face (Kattan et al. 2004; Rabinowitz and Zeller 2010; García-Rangel 2012; Caceres-Martinez and Acevedo 2014; Pizarro 2015) in absence of appropriate conservation planning (O'Brien 2008), even when an area is actively managed for conservation. Moreover, significant extents of Andean forests and Páramos in La Carpa and La Rochela, within the buffer zone, are not currently included in the official 
NNP limits. Our results indicate the presence of large species such as T. ornatus and $P$. concolor in these areas, being both critical for the connection with protected Páramos (e. g., La Cabrera and Tamá) and to the Venezuelan park, thus highlighting the need for expanding the park limits to include these areas. Although these areas are under park management, still there are many threats such as hunting, deforestation and conflict that still operate in these areas given the lack of enforcement, especially when it still occurs within the official portions of the Tamá NNP.

Threats such as illegal hunting are still considerably high in the region with potential significant impacts on medium and large mammals (Caceres-Martinez and Acevedo 2014). In addition, the advance of agriculture practices and land use transformation is also evident in the area, which together with hunting imposes a more severe threat to mammal populations. Considering the importance of this protected area, these threats need to be urgently controlled given the important mammal diversity the area still comprises (Woodman 2002; Armenteras et al. 2003; Caceres-Martinez and Acevedo 2014; Cáceres-Martínez et al. 2015). We expect this first effort of documenting mammal diversity in the park will contribute to the management and conservation of this important protected area of Colombia. Further efforts, however, should focus on assessing the conservation status and ecology of these populations together with providing more tools for the appropriate management and planning of the park.

\section{Acknowledgements}

This project was executed under permit No. 011 of 2013 and resolution No. 114 from August 13th 2015 granted by Parques Nacionales de Colombia. Financial and logistical support for the project was provided by Fundación Alejandro Escobar (FAAE), WCSColombia, IDEA WILD, Parques Nacionales de Colombia, Parque Nacional Natural Tamá, Vicerrectoría Academica and Vicerrectoría de Investigaciones of Universidad de Pamplona, and Alianza para la Conservación del Oso Andino (ABCA). Especial thanks to I. Goldstein, R. Marquez, and A. M. Cage, for their valuable and essential help through the development of this project. Thanks to L. Sanchez and R. V. Horn for their assistance in the revision of the text, and to J. Contreras, A. Cáceres, A. Cáceres, C. Acevedo, D. Maldonado, D. González, E. Contreras, F. Cáceres, G. Delgado, H. Vega, J. Reyes, M. Barajas and the staff from Tamá NNP, for their contribution on the field stage of the project.

\section{References}

Aranda, M. 2012. Manual para el rastreo de mamíferos silvestres de México. México: Comisión Nacional para el Conocimientos y Uso de la Biodiversidad. Ciudad de México, México.

Armenteras, D., F. Gast, and H. Villareal. 2003. Andean forest fragmentation and the representativeness of protected natural areas in the eastern Andes, Colombia. Biological Conservation 113:245-256.

Barrio, J. 2010. First records and conservation status of Mazama rufina (Cervidae, Artiodactyla) from Perú. Mastozoología Neotropical 17:117-122.

Blake, J. G., D. Mosquera, B. A. Loiselle, K. Swing, J. Guerra, and D. Romo. 2012. Temporal activity patterns of terrestrial mammals in lowland rainforest of eastern Ecuador. Ecotropica 18:137-146.

Cáceres-Martínez, C. H., and A. Acevedo. 2014. Primer registro fotográfico de Tremarctos ornatus (Carnivora: Ursidae) y de Puma concolor (Carnivora: Felidae) en el Parque Nacional Natural Tamá, Norte de Santander, Colombia. Mammalogy Notes 1:5-7. 
Cáceres-Martínez, C. H., A. Acevedo, and L. R. Sánchez. 2015. Registros plásticos en la ingesta de Tremarctos ornauts (Carnivora: Ursidae) y de Nasuella olivacea (Carnivora: Procyonidae) en el Parque Nacional Natural Tamá Colombia. Revista Mexicana de Biodiversidad 86:839-842.

Castaño, J. H., Y. Muñoz-Saba, J. E. Botero, and J. H.Vélez. 2003. Mamíferos del departamento de Caldas-Colombia. Biota Colombiana 4:247-259.

Castellanos, A., M. Altamirano, and G. Tapia. 2005. Ecología y comportamiento de osos andinos reintroducidos en la Reserva Biológica Maquipucuna, Ecuador: implicaciones en la conservación. Revista Politécnica 26:54-82.

Ceballos, G., AND J. H. Brown. 1995. Global patterns of mammalian diversity, endemism, and endangerment. Conservation Biology 9:559-568.

Ceballos, G., and G. Oliva (eds.). 2005. Los mamíferos silvestres de México. CONABiO UNAM - Fondo de Cultura Económica. Ciudad de México, México.

Colwell R. K. 2013. EstimateS: Statistical estimation of species richness and shared species from samples. Version 9. User's Guide and application.

Emmons, L.H., and F. Feer. 1997. Neotropical rainforest mammals: a field guide. University of Chicago Press. Chicago, U. S. A.

Espinosa T. E. 2003. ¿Cuántas especies hay? Los estimadores no paramétricos de Chao. Elementos 52:53-56.

Forero-Medina, G., AND L. Joppa. 2010. Representation of global and national conservation priorities by Colombia's protected area network. PLoS One 5(10): e13210.

García-Rangel, S. 2012. Andean bear Tremarctos ornatus natural history and conservation. Mammal Review 42:85-119.

Goldstein, I., R. Márquez, J. Martínez, A. Cifuentes, A. Pérez, A. Melchor, C. Herrera, and G. BiAnchI. 2013. Manual para el monitoreo de oso andino en los Parques Nacionales Naturales de Colombia. Wildlife Conservation Society. Parques Nacionales Naturales de Colombia. Bogotá, Colombia.

González-Maya, J. F., J. Schipper and A. Benítez. 2009. Activity patterns and community ecology of small carnivores in the Talamanca region, Costa Rica. Small Carnivore Conservation 41:9-14.

González-Maya, J. F., D. Zárrate-Charry, I. M. Vela-Vargas, J. S. Jiménez-Alvarado and D. A. Gómez-Hoyos. 2015. Activity patterns of Tayra Eira barbara populations from Costa Rica and Colombia: evidence of seasonal effects. Revista Biodiversidad Neotropical 5:96-104.

Gutiérrez, E. E., J. E. Maldonado, A. Radosavljevic, J. Molinari, B. D. Patterson, J. M. Martínez-C., A. R. Rutter, M. Hawkins, F. J. Garcia, and K. M. Helgen. 2015. The Taxonomic Status of Mazama bricenii and the Significance of the Táchira Depression for Mammalian Endemism in the Cordillera de Mérida, Venezuela. PLoS One 10(6): e0129113.

Guzmán-lenis, A., and A. Camargo-Sanabria. 2004. Importancia de los rastros para la caracterización del uso de hábitat de mamíferos medianos y grandes en el bosque Los Mangos (Puerto López, Meta, Colombia). Acta Biológica Colombiana 9:11-22.

HoldRIDGE, L. R. 1987. Ecología basada en zonas de vida: Instituto Interamericano de Cooperación para la Agricultura. San José, Costa Rica.

Jaksié, F. M., H. W. Greene and J. L. Yáñez. 1981. The guild structure of a community of predatory vertebrates in central Chile. Oecologia 49:21-28.

Jiménez, C. F., H. Quintana, V. Pacheco, D. Melton, J. Torrealva, and G. Tello. 2010. Camera trap survey of medium and large mammals in a montane rainforest of northern Peru. Revista peruana de Biología 17: 91-196. 
Kattan, G. H., and P. Franco. 2004. Bird diversity along elevational gradients in the Andes of Colombia: area and mass effects. Global Ecology and Biogeography 13:451-458.

Kattan, G., L. Hernández, I. Goldstein, V. Rojas, O. Murillo, C. Gómez, H. Restrepo, and F. Cuesta. 2004. Range fragmentation in the spectacled bear Tremarctos ornatus in the northern Andes. Oryx 38:155-163.

Lira-Torres, I and M. Briones-Salas. 2012. Abundancia relativa y patrones de actividad de los mamíferos de los Chimalapas, Oaxaca, México. Acta Zoológica Mexicana (n. s.) 28:566-585.

Lizcano, D., and S. J. Alvarez. 2008. Mazama rufina. The IUCN Red List of Threatened Species 2008: e.T12914A3397972. http://www.iucnredlist.org, 13 July 2015.

Lizcano, D. J., E. Yerena, S. Alvarez, and J. R. Dietrich. 2010. Mérida brocket Mazama bricenii (Thomas 1908). Neotropical Cervidology: biology and medicine of Latin American deer. 20:181-184.

Merino, M. L., AND R. V. Rossi. 2010. Origin, systematics and morphological radiation. Neotropical Cervidology. Biology and medicine of Latin American deer 1:2-11.

Minambiente. 2008. Plan De Manejo Parque Nacional Natural Tamá 2006-2010. Ministerio de Medio Ambiente, Vivienda y Desarrollo Territorial. Unidad Administrativa Especial del Sistema de Parques Nacionales Naturales. Dirección Territorial Norandina. Bogotá, Colombia.

Mosquera-Muñoz, D.M., G. Corredor, P. Cardona, and I. Armbrecht. 2014. Fototrampeo de aves caminadoras y mamíferos asociados en el piedemonte de Farallones de Cali. Boletín Científico Centro de Museos Museo de Historia Natural Universidad de Caldas 18:144-156.

Norris, D., J. M. Ramírez, C. Zacchi, and M. Galetti. 2012. A survey of mid and large bodied mammals in Núcleo Caraguatatuba, Serra do Mar State Park, Brazil. Biota Neotropica 12:127-133.

O'Brien, T. G. 2008. On the use of automated cameras to estimate species richness for largeand medium-sized rainforest mammals. Animal Conservation11:179-181.

Pérez-Irineo, G., And A. Santos-Moreno. 2013. Trends in research on terrestrial species of the order carnivora. Mastozoología Neotropical 20:113-121.

Pizarro, J. F. 2015. Interacciones humano-oso andino Tremarctos ornatus en el Perú: consumo de cultivos y depredación de ganado. Therya 6:251-278.

Prado, J. C., and D. Bonilla. 2009. Pequeños mamíferos no voladores de la reserva natural Ibanasca (Tolima, Colombia). Tumbaga 1:121-134.

Rabinowitz, A., And K. A. Zeller. 2010. A range-wide model of landscape connectivity and conservation for the jaguar, Panthera onca. Biological Conservation 143:939-945.

Ramírez-Chaves, H., A. Suárez-Castro., and J. F. González-Maya. 2016. Cambios recientes a la lista de los mamíferos de Colombia. Mammalogy Notes 3:1-21.

R CORE Team. 2013. R: A language and environment for statistical computing. $R$ foundation for Statistical Computing. Vienna, Austria.

Ramírez, H. E., and W. A. Pérez. 2006. Mamíferos de un fragmento de bosque de roble en el departamento del Cauca-Colombia. Boletín Científico Centro de Museos Museo de Historia Natural Universidad de Caldas 11:65-79.

Ramírez-Chaves, H. E., and E. A. Noguera-Urbano. 2010. Lista preliminar de los mamíferos (Mammalia: Theria) del departamento de Nariño, Colombia. Biota Colombiana 11:117-140.

Ramírez-Chaves, H. E., E. A. Noguera-Urbano, and M. E. Rodríguez-Posada. 2013. Mamíferos (Mammalia) del departamento de Putumayo, Colombia. Revista de la Academia 
Colombiana de Ciencias Exactas, Físicas y Naturales 37:263-286.

Ramírez-chaves, H. E., A. F. Suárez-Castro, and B. D. Patterson. 2014. Re-examining the hypothesis of allopatric distribution of Myoprocta acouchy and M. pratti (Mammalia: Dasyproctidae) in South America. Papéis Avulsos de Zoologia (São Paulo) 54:447-456.

Richter, S. M., and E. M. Schauber. 2006. Distribution of the long-tailed weasel (Mustela frenata) in Illinois. Transactions of the Illinois State Academy of Science 99:153-161.

Rodríguez-Mahecha, J. V., M. Alberico, F. Trujillo, and J. Jorgenson (eds.). 2006. Libro rojo de los mamíferos de Colombia. Serie libros rojos de especies amenazadas de Colombia. Conservación Internacional Colombia, Instituto de Ciencias Naturales - Universidad Nacional de Colombia, Ministerio del Medio Ambiente. Bogotá, Colombia.

Rodríguez-Posada, M. E. 2010. Murciélagos de un bosque en los Andes Centrales de Colombia con notas sobre su taxonomía y distribución. Caldasia 32:205-220.

Rust, C. C. 1962. Temperature as a modifying factor in the spring pelage change of shorttailed weasels. Journal of Mammalogy 43:323-328.

Sánchez, F., P. Sánchez-Palomino, and A. Cadena. 2004. Inventario de mamíferos en un bosque de los andes centrales de Colombia. Caldasia 26:291-309.

Setina, V., D. J. Lizcano, D. M. Brooks, and L. F. Silveira. 2012. Population density of the helmeted curassow (Pauxi pauxi) in Tamá National Park, Colombia. The Wilson Journal of Ornithology 124:316-320.

Sмrтнe, N. 1978. The natural history of the Central American agouti (Dasyprocta punctata). Smithsonian Contributions to Zoology 257:1-52.

Solari, S., Y. Muñoz-Saba, J. V. Rodríguez-Mahecha, T. R. Defler, H. E. Ramírez-Chaves, and F. Trujillo. 2013. Riqueza, endemismo y conservación de los mamíferos de Colombia. Mastozoología Neotropical 20:301-365.

Tobler, M. W., S. E. Carrillo-Percastegui, R. Leite Pitman, R. Mares, and G. Powell. 2008. An evaluation of camera traps for inventorying large-and medium-sized terrestrial rainforest mammals. Animal Conservation 11:169-178.

White, P. C., N. V. Jennings, A. R. Renwick, and N. H. Barker. 2005. Review: questionnaires in ecology: a review of past use and recommendations for best practice. Journal of Applied Ecology 42:421-430.

Wilson, D. E., And D. M. Reeder (eds.). 2005. Mammal species of the World: a taxonomic and geographic reference. The Johns Hopkins University Press. Baltimore, U. S. A.

Woodman, N. 2002. A new species of small-eared shrew from Colombia and Venezuela (Mammalia: Soricomorpha: Soricidae: Genus Cryptotis). Proceedings-Biological Society of Washington 115:249-272.

Zapata-Ríos, G., AND L. C. Branch. 2016. Altered activity patterns and reduced abundance of native mammals in sites with feral dogs in the high Andes. Biological Conservation 193:9-16.

Summited: April 18, 2016

Review: May 19, 2016

Accepted: May 24, 2016

Associated editor: Sergio Solari 